\title{
Central-European Jesuit Scientists in China, and Their Impact on Chinese Science
}

\author{
Stanislav JUŽNIČ́
}

\begin{abstract}
This article describes nine Central European Jesuits from the Austrian province who embarked for China in the 17th and 18th centuries. Their European educational networks provide useful insights into the abilities of the Habsburg Monarchy to meet Chinese Imperial demands. The focus is on feedback of their adopted Chinese network back to their own homes. The Europeans and Chinese-based Jesuits exchanged instruments, books, artifacts, and letters. The exception was Johannes Grueber, who personally traveled back to Europe accompanied by Diestel from Carniola, and helped Athanasius Kircher to produce the appealing legend of Jesuit astronomical heroes in Beijing.

The Jesuits acted as intermediate in the exchange of know-how between Europe and China. In modern Chinese eyes they were also somewhat viewed as spies, who helped European military and economic victories in the mid-19th century. Modern China is now as strong as it was in the times of Old Jesuit Society, therefore the Europocentric history of science must be rewritten from the standpoint of today's winning Chinese economy. What kind of science will Western Civilization import from the future Chinese literati? The Jesuits' transfer of European Sciences to the Far-Easterners caused the reverse impact from seemingly less developed centers of Far East that was felt in Jesuits' times, but much more is to follow in the near future. We could expect the fundamental future Chinese achievements in cosmology, especially in Einstein's general theory of relativity.
\end{abstract}

Keywords: China-based Jesuits, Central European Educational Network of Jesuits, Hallerstein, Ljubljana.

\section{Izvleček}

$\mathrm{V}$ pričujočem članku je opisanih devet srednjeevropskih jezuitov iz avstrijske province, ki so delali na Kitajskem v 17. in 18. stoletju. Njihove evropske izobraževalne mreže zagotavljajo koristen vpogled v tedanje možnosti Habsburške monarhije za izpolnjevanje potreb Kitajskega imperija. Izpostavljene so povratne informacije o jezuitskem raziskovanju kitajske mreže znanj poslane nazaj v domače evropske logove. Evropejci in jezuiti na Kitajskem so medsebojno izmenjevali znanstvene instrumente, knjige, umetnine in pisma. Le Johannes Grueber je v spremstvu Kranjca Diestela osebno odpotoval nazaj v dobro

Stanislav JUŽNIČ, Professor, Head of the Archive of

Slovenian Province of Jesuits, Slovenia.

juznic@hotmail.com

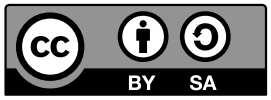


staro Evropo in pomagal Athanasiusu Kircheru zasnovati privlačno legendo o pekinških znanstvenih junakih jezuitske astronomije.

Jezuiti so delovali kot vmesni člen v evropsko-kitajski izmenjavi znanja in izkušenj. $\mathrm{V}$ sodobnih kitajskih očeh so bili tudi svojevrstni vohuni, ki so po svoje pripomogli $\mathrm{k}$ evropskim vojno-gospodarskim zmagam nad Kitajci sredi 19. stoletja. Sodobna Kitajska je zdaj spet močna, kot je bila v časih stare jezuitske Družbe, zato potrebujemo revizijo evro-centrične zgodovine znanosti predelane s stališča današnjega zmagovalnega kitajskega gospodarstva. Kakšno znanosti bo zahodnjaška civilizacija uvažala od prihodnjih kitajskih učenjakov? Jezuitski prenos evropske znanosti na Daljni Vzhod je povzročil obraten prenos znanj iz na videz manj razvitih središč Daljnega Vzhoda, kar je bilo čutiti v jezuitskih časih, veliko več pa bo sledilo v bližnji prihodnosti. Predvsem lahko pričakujemo temeljne prihodnje kitajske dosežke $\mathrm{v}$ kozmologiji, še posebej pa $\mathrm{v}$ Einsteinovi splošni teorije relativnosti.

Ključne besede: kitajski jezuitski misijonarji, srednjeevropska jezuitska izobraževalna mreža, Hallerstein, Ljubljana.

\section{Introduction}

The purpose of this article is to provide previously unpublished data about Central European China-based Jesuits and their role in the reciprocal exchange of European and Chinese know-how. Two effects of their works are examined: the Chinese military and economic humiliations a century after the Jesuits stopped performing their role as intermediaries, and the effects of the successful modern development of the Chinese economy after another century. The last fact is used as challenge to rewrite the history of science from the Chinese, now victorious, standpoint, where the Chinese literati will figure as the winners that dictate the historical truth, and the Westerners as the losers that dictated their own historical facts yesterday, but which proved to be wrong and too Eurocentric in modern Far-Eastern eyes. The real historical truth, as always, seems to be somewhere in between the Eurocentric and "China-centric" standpoints, which is exactly the standpoint of China-based Jesuits from the Old Society and especially their Central European members based in both parts of the world. The aim of this article is to support the future combination of historical approaches in the spirit of Ricci's adaptation, which is also mirrored in artist Huiqin Wang's modern imagination of astronomer Augustin Hallerstein and painter Giuseppe Castiglione.

The study methods used are based on an analysis of Jesuits' central European sources covering the network of Jesuit schools. Their aim was to produce the missionaries, and the China mission was the pearl of them all. After the 
analysis of Central European network production, the role of Jesuit missionaries in the interchange between seemingly incommensurable Chinese and $\mathrm{Eu}-$ ropean know-how is documented by the writing, instruments, and material backing of China-based Jesuits. The final goal is the projection of future Chinese influences onto explanations of the challenges of the history of sciences and on modern scientists themselves, who will eventually became the object of the history of sciences.

The Jesuits of Old Society managed a highly centralized network. Their missionary work in China was one of their main raisons d'etre, the pearl of their worldwide achievements. The temporarily success of Christianity in China justified the Jesuits' otherwise not-always-fair thirst for power in the most formidable way, also because of the huge number of Chinese Christian converts endorsed before the Jesuits lost the Chinese Rites Controversy in the early 18th century. The important part of the Jesuits' self-image was their scientific network mixed with the native Chinese scientific network, which had a fundamentally different cultural-social background. The Japanese expelled their Jesuits very early. The interchange of European and Chinese scientific networks remained the most relevant example ever accomplished. The Western Europeans launched similar encounters with much more European-related Islamic and Indian scientific networks. The European Christians destroyed most other local civilization's scientific networks before they were able to interact with them in the Americas, Sub-Saharan Africa, Australia, or the Pacific islands.

The idea of White Male Christian exclusivity is used in the modern history of science as an excuse for racist and genocidal destruction of all others except (Far) Eastern cultures and sciences. The Western Christians launched a Blitzkrieg against all other cultures' sciences except the (Far) Eastern. In China, Constantine the Great's (272-337) model of nationwide conversion from the top down was slowly being prepared instead. In G. Gruber's Russia, and for a few decades in Japan, the Jesuits also dreamed about the Constantinian model. Because the number of Chinese surpassed the number of Europeans, Western Christians were forced to think about the Chinese as the subjects, and not just as objects for the possible conversion to Christianity, and their subsequent inclusion into global market system.

\section{What Did it Feel Like to Be a Jesuit (in China)?}

This is the hardest question of them all. The present author collaborates with the Jesuits of the Slovenian Province and of Saint Louis University in USA, but their 
framework happens to be much narrower than the monopoly on Catholic education that their predecessors of the old Jesuit society held up to 1773. Despite the fact that modern Jesuits resemble their predecessors in all visual aspects, they are far less powerful in the modern, global, pluralistic society.

The Jesuits of the Old Society were proud elite. They were almost never openly racist in foreign lands. They followed the main rule of every missionary outpost and accepted as many domestic Chinese novices as possible in a persistent effort to make their Chinese headquarters work independently from the inflow of $\mathrm{Eu}$ ropean Jesuit newcomers. They never succeeded in that goal and their Chinese headquarters simply died out after the inflow of European newcomers stopped in 1773. The Bishop Laimbeckhoven (1701 in Wien-Mai 22, 1787) had to order the suppression of the Jesuits in the Bishopric of Nanking and Beijing on June 17, 1775 (Kaminski 1996, 33; Kaminski and Unterreider 1980, 70). There was simply not enough operational freedom for Chinese Catholics to fulfill the task and develop self-persistent colleges in China. To make the situation worse, the Beijing Imperial Court (wrongly) judged that its domestic servants had learned enough about science and technology from the Jesuits to run future research on their own.

There is also one important difference between Jesuits and most other Catholic religious orders, namely that the Jesuits of the old Society did not accept females in their order and did not develop a female branch of the Jesuit order despite the legend of Juana (Joanna) of Austria, the Princess of Portugal (1535-1573). The rule certainly also applied to Chinese women, who never played any prominent roles in the Jesuits' scientific network (Mungello 2009, 26, 36, 59).

\section{The Jesuits' Worldwide Network}

Jesuits science was a strictly centralized enterprise designed to help the conversions of infidels from foreign cultures, who more or less believed in the proposed superiority of European Christian know-how over the supposedly inferior local achievements of the infidels. In the Chinese case, (the history of) local science was the only one judged by Europeans to be worth of studying worldwide, while most other Non-European sciences were destroyed without remorse. Although the Jesuits' primary aim was to fight back the Protestants, the leading Jesuit Francis Xavier (1506-1552) spent his last decade in the Far East. He opened the Jesuit enterprise, which lasted there for two and a half centuries. A few weeks before his death Matteo Ricci (1552-1610) was born, and in 1578 Ricci was sent abroad to put Francis's beginnings into a solid framework, which stood firm up to Hallerstein's times. 
The Jesuits' European educational network constantly produced thousands of industrious Jesuits in their early thirties. Among them, those nobles with mathematical interests were preferred for possible missionary work in China under Portuguese and later also under French flags. Nobles with mathematical training included the baron Hallerstein and von Laimbeckhoven, whose mother grew up in Vienna as a closest friend of Habsburg princess. The majority of the chosen Chinese missionaries died due to the unfavorable travel circumstances during their approximately one-year trip to the Far East. Those who survived created the legend published for the first time in the anthologies of the Roman Jesuit mathematician Athanasius Kircher (1602-November 27, 1680) after Johannes Grueber (28 October 1623 Linz-30 September 1680) reached Rome with fresh exciting news from Beijing. The question of the modern observer is: what made the Jesuits so dedicated as to risk their young lives for the collective enterprise of the Jesuit order? The only possible answer was included in the training and education in Jesuit's European headquarters, where they usually studied for at least a decade and a half. During their schooling the Jesuits learned about the legends of their order and finally promised their absolute willingness to travel for any destination including China. They became the perfect missionaries and their scientific know-how was used as their Trojan horse, even if the last generations of Beijing-based Jesuits began to treat (astronomical) sciences as their primary focus (Južnič 2015, 6).

\section{Jesuits' Network of Austrian Province of German Assistance}

The Austrian Province of Jesuits, which ceded from the Bohemian Province in $1622 / 23$, was an important resource for mathematically trained Jesuits dedicated to travelling to China under the Portuguese flag. Their missionary work was a regular, everyday part of life in the Austrian province due to their proximity to the Turkish border. The appeal of the overseas and especially Chinese mission was much also greater because the Beijing Court was among the rare ones that demanded scientific skills from European newcomers. The door for the future Chinese missionaries from the Austrian province opened wide after the Habsburg princess Maria Anna married the Portuguese king Joao V in 1708. China was certainly not the primary destination for the missionaries of the Austrian Jesuit province. In 1733, just Fridelli was in China, while his fellow Jesuits from the Austrian province served in Goa (one Jesuit), Malabaria (Kerala, south of Goa, 2 Jesuits), Philippines (3), Mexico (2), Nuovo Regno (di Granada in present Columbia, 3) Peru (1), Quito (4), Chile (3), Buenos Aires (1), and five Jesuits from Austrian Province worked in Paraguay, including Hallerstein's 
uncle Innocent Erberg. In 1750 Hallerstein, Neugebauer, and Laimbeckhoven served in China, but 57 other missionaries from the Austrian Jesuit province served in other overseas destinations, mostly in Latin America (Jesuits 1733: column 41; Jesuits 1750: columns 48-9).

Between 1552 and 1800, out of 920 China-based Jesuits 314 were Portuguese, 130 French, and 99 Italians (Mungello 2009, 37). The Austrian Jesuit province educated at least 9 China-based Jesuits' missionaries, one percent of them all. These were Andreas Wolfgang Koffler (1612 Vienna-1651), Johannes Grueber (1623 Linz-1680), Bernard Diestel (1623 Vipava-1660), Christian Wolfgang Herdtrich (1625 Peggau north of Graz-1684), Xavier Ehrenbert Fridelli (1673 Linz-1743), Johann Baptist Mesar (Messari, 1673 Mesarji by Branik-1723), Augustin Hallerstein (1703 Ljubljana-1774), Joseph Chrysostom Neugebauer (1706 Franckenstein (Ząbkowice Śląskie south of Wroclaw) in Silesia-1759?), and Laimbeckhoven (1707 Vienna-1787). One of their predecessors in China, the Croatian from Venetian Split Ivan Ureman (1583-1621), entered the Jesuit society in Rome. The Austrian Jesuit province did not share exactly the same borders with the Habsburg monarchy and Kircher's student Martin Martini (Wei K'ouang-Kouo, Tsi-T'ai, 1614 Trente (Trident), the capital of today's Italian part of Tyrol; SJ 1632 Rome; -1661 Hangchow (Koláček 1999, 17; Južnič 2015, 14, 19-20)) never belonged to the Austrian province, although he was born as a Habsburg subject. Václav Pantaleon Kirwitzer (Wenzel Pantaleon Kirwitzer, Wenceslaus Kirwitzer, Wenceslas Pantaleon Kirwitzer, 祁維材 Qi Weicai, 1588 or 1590 Kadaň in Bohemia; SJ 28/2/1606 Brno; -22/5/1626 Macao) worked in China from 1620 to 1626 . He was originally a member of the Austrian province until 1622/23 when his Bohemian (Czech) province became independent, and he is therefore not taken into account in this study. 


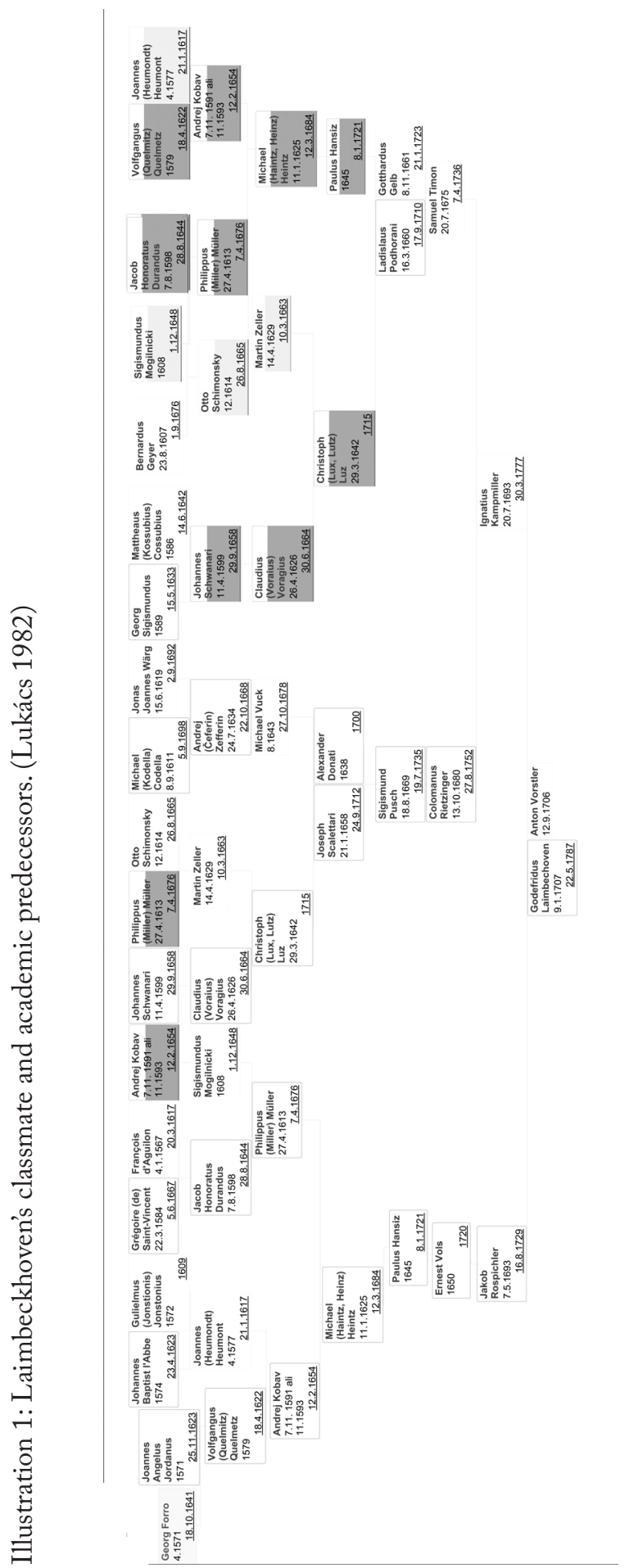


Table 1: Statistic of the China-based Jesuits from Austrian Province

\begin{tabular}{|c|c|c|c|c|}
\hline $\begin{array}{l}\text { Name/domi- } \\
\text { cile in Austria, } \\
\text { Silesia, Styria, } \\
\text { or Carniola }\end{array}$ & $\begin{array}{l}\text { European } \\
\text { Alma Mater } \\
\text { in Phi- } \\
\text { losophy }\end{array}$ & $\begin{array}{l}\text { European } \\
\text { Experience in } \\
\text { Sciences and / } \\
\text { or Technology }\end{array}$ & $\begin{array}{l}\text { Age while } \\
\text { working in } \\
\text { China }\end{array}$ & $\begin{array}{l}\text { Chinese Work in } \\
\text { Science/Technology }\end{array}$ \\
\hline Koffler/A & Graz & I & $33-40$ & $\begin{array}{l}\text { Court Calendar Re- } \\
\text { parations }\end{array}$ \\
\hline Grueber/A & Graz & I & $33-40$ & $\begin{array}{l}\text { Professor of mathe- } \\
\text { matics helping Adam } \\
\text { Schall von Bell } \\
\end{array}$ \\
\hline Diestel/C & Graz & $\begin{array}{l}\text { Professor of } \\
\text { mathematics in } \\
\text { Graz }\end{array}$ & $35-37$ & $\begin{array}{l}\text { Helping Bell in his } \\
\text { astronomical obser- } \\
\text { vatory }\end{array}$ \\
\hline Herdtrich/St & Vienna & / & $32-59$ & $\begin{array}{l}\text { Court mathematician } \\
\text { as Verbiest's collabo- } \\
\text { rator, astronomer in } \\
\text { Beijing in the } 1670 \text { s } \\
\end{array}$ \\
\hline Fridelli/A & Vienna & $\begin{array}{l}\text { Repeater of } \\
\text { mathematics in } \\
\text { Vienna on ad- } \\
\text { vanced study }\end{array}$ & $32-70$ & Cartographer \\
\hline Mesar/C & Gorizia & 1 & $36-50$ & 1 \\
\hline Hallerstein/C & Ljubljana & $\begin{array}{l}\text { Repeater of } \\
\text { mathematics in } \\
\text { Vienna, studied } \\
\text { mathematical } \\
\text { sciences in Lis- } \\
\text { bon 1735-1736 }\end{array}$ & $35-71$ & $\begin{array}{l}\text { Head of Astronomi- } \\
\text { cal Bureau }\end{array}$ \\
\hline Neugebauer/Si & 1 & $\begin{array}{l}\text { Carpenter ex- } \\
\text { perienced in } \\
\text { buildings }\end{array}$ & $31,44-46$ & $\begin{array}{l}\text { Cartographer in } \\
\text { Macao }\end{array}$ \\
\hline $\begin{array}{l}\text { Laimbeckho- } \\
\text { ven/A }\end{array}$ & Graz & $\begin{array}{l}\text { Repeater of } \\
\text { mathematics in } \\
\text { Vienna, studied } \\
\text { mathematical } \\
\text { sciences in Lis- } \\
\text { bon } 1735-1736\end{array}$ & $31-80$ & $\begin{array}{l}\text { Reported about the } \\
\text { pharmacopoeia, me- } \\
\text { dicine, observation of } \\
\text { the eclipses of Moon } \\
\text { and of comets }\end{array}$ \\
\hline
\end{tabular}

All future Chinese missionaries from the Austrian province were educated in Graz or Vienna except for the preacher Mesar, the only one who was not trained 
for mathematical work. The older generation of China Jesuits from the Austrian Jesuit province, including Johannes Grueber and Fridelli, belonged to the same educational milieu of Swiss Paul Guldin (1577-1643) and his collaborator from Cerknica in Carniola Andreas Kobav (1593/94-1654) in the Jesuit University of Graz. Graz students were also their contemporaries, like the future China Jesuits Koffler (1612 Vienna-1651) and J. Grueber's travel companion Diestel. But their professor of mathematics Durandus (1598-1644) eventually came from Low Countries (Netherland) as did Durandus' Professors Saint-Vincent (22 March 1584-5 June 1667) and d'Aguillon (4 January 1567-20 March 1617). The mathematical training offered in the Low Countries was among the best in the Catholic circle even later in the eighteenth century when former Leyden student Gerhard van Swieten (1700-1772) and his group reformed the education system of Habsburg monarchy.

\begin{tabular}{|c|}
\hline $\begin{array}{l}\text { Pedro } \\
\text { (Nonius) } \\
\text { Nunes } \\
1502\end{array}$ \\
\hline
\end{tabular}

\section{Christopher \\ Clavius \\ 25.3.1538 \\ $\underline{6.2 .1612}$}

Grégoire (de)

Saint-Vincent

22.3.1584

$\underline{5.6 .1667}$

\section{Pedro (da) \\ Fonseca \\ 1528}

$\underline{4.11 .1599}$

\section{François}

d'Aguilon

4.1.1567

$\underline{20.3 .1617}$

\begin{tabular}{|c|c|c|c|}
\hline $\begin{array}{l}\text { Jacob } \\
\text { Honoratus } \\
\text { Durandus } \\
\text { 7.8.1598 } \\
\quad \underline{28.8 .1644} \\
\end{array}$ & $\begin{array}{l}\text { Paulus } \\
\text { Rosmer } \\
1605\end{array}$ & $\underline{1664}$ & \multirow[b]{2}{*}{$\begin{array}{l}\text { Joannes } \\
\text { Baptist } \\
\text { Rovera } \\
\text { 24.6.1622 } \\
\quad \underline{21.12 .1671}\end{array}$} \\
\hline \multicolumn{2}{|c|}{$\begin{array}{l}\text { Bernhard (de } \\
\text { Estel) Diestel } \\
13.7 .1623 \\
13.9 .1660 \\
\end{array}$} & $\begin{array}{l}\text { Otto } \\
\text { Schimonsky } \\
12.1614 \\
\underline{26.8 .1665} \\
\end{array}$ & \\
\hline \multicolumn{2}{|c|}{$\begin{array}{l}\text { Janez Ditrih } \\
\text { Valvasor } \\
1633\end{array}$} & $\begin{array}{l}\text { Feliks } \\
\text { Coronino } \\
14.1 .1632\end{array}$ & \\
\hline
\end{tabular}

1.1.1718

Illustration 2: Academic predecessors, classmates, collaborators, and students of China-based Jesuit Diestel from Vipava. (Lukács 1982) 
The education of future China-based Jesuits was a prelude for the founding of their journeys, and the books and scientific instruments needed for their work in China. The most foundations were based in the Central European milieu of the Holy Roman Empire. The leading Chinese scientist Hallerstein was able to find his supporters in Portugal where the Queen proved to be especially helpful for his career. Hallerstein's early Portuguese and later Beijing networks included the Portuguese Jew Antonio-Nuñes Ribeyra Sanchez (Ribeiro Sanches, 1699 Penna-Macor-1783 Paris), although Hallerstein eventually never met him in Portugal. Sanchez and his networks in St. Petersburg and London supplied Hallerstein in Beijing with scientific instruments and books in a kind of exchange for Hallerstein information and artifacts appreciated by the curious European Literati.

Hallerstein and Laimbeckhoven's travel companion on their trip to the Far East was Neugebauer. Neugebauer certainly had one of the most extraordinary careers among the Jesuits, because in his Viennese times (1730-1736) he was trained as a carpenter experienced in buildings and box-manufacturing (Jesuits 1730: column 24; Jesuits 1732: column 30). In Europe he was not a priest, but a temporary helper without university training, as was his older Jesuit companion, the court painter Giuseppe Castiglione (1688-1766). The Habsburgs occupied Castiglione's native Milan after 1701. Neugebauer did not wait for long in Lisbon before they embarked on April 26, 1737, but he might have learnt some astronomy from Hallerstein and Laimbeckhoven during the months of their joint travel. They put the anchor together in Macao on September 4, 1738. In 1738 Hallerstein fulfilled the wish of the governor of Macao and mapped the city, along with its surroundings. The work was printed the next year in French and put at the governor's disposal. Neugebauer copied the map for the king of Portugal. Because of those collaborations, we might accept Neugebauer as the informal student of Hallerstein and also of Laimbeckhoven. Laimbeckhoven was very interested in astronomy before his pastoral work in the position of bishop of Nanking deprived him of the necessary opportunities. On October 10, 1739, Laimbeckhoven reported about the Chinese pharmacopoeia and medicine. On December 3, 1739, he wrote to Europe about the preventive measures needed to observe the eclipses of the moon in Macao. Laimbeckhoven described comets visible in 1755 and in May-June 1759 , in a letter mailed to his sister Maria Elisabetha von Sumerau sent on May 28, 1760, and in a letter mailed to her husband Antonius Thadeus von Sumerau on April 20, 1761. The fascinating Halley's Comet disappeared on April 26, 1759, and Laimbeckhoven observed it again in the Leo constellation on May 15, 1759, (Stoeger 1855, 201; Dežman 1881, 4, 9; Laimbeckhoven 2000, 97, 110; Amiot 1774, 557, 558). 


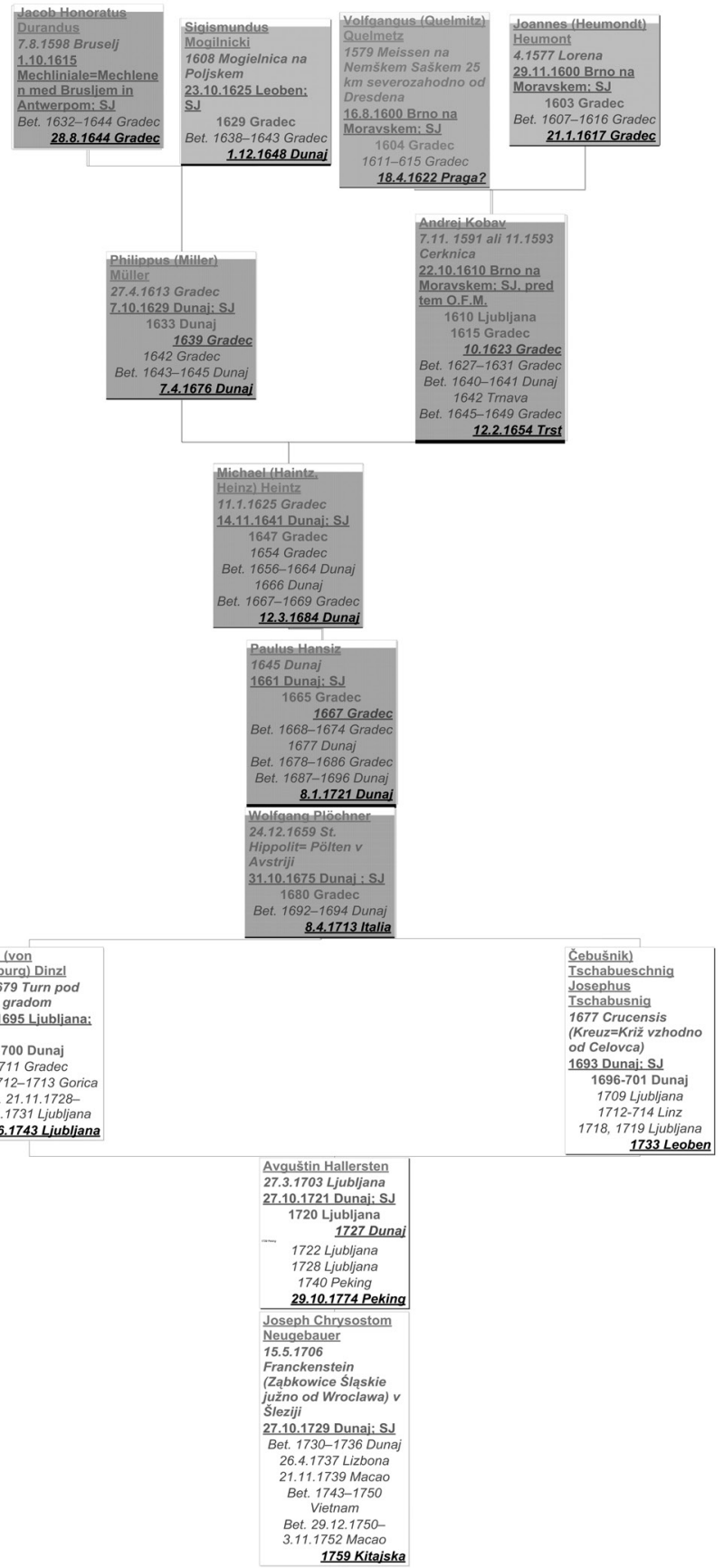

Illustration 3: Neugebauer's academic ancestors related to his informal studies with Hallerstein. (Lukács 1982) 
After their joint work in Macao the paths of Hallerstein, Laimbeckhoven, and Neugebauer divided. Neugebauer eventually became a priest in Gia Định (嘉 定, today's Ho Chi Minh City) in Vietnam (Cochinchina) on May 28 1741. In Vietnam Neugebauer developed such extraordinary talents in astronomy and architecture that he was promoted to the rank of Mandarin. After the Jesuits were expelled from Vietnam, Neugebauer resided in Macao again from 1750 to 1752. All the time he corresponded with his fellow Jesuit Ignatius Heinn (Heindl, 1709 Klagenfurt; SJ 1725 Vienna-after 1773) who studied in Graz (1731-1739) and worked as superior in Steyr in 1750-1762.

\section{Jesuits' Network of Ljubljana College}

Ljubljana had the unique Jesuits' college of Carniola, although this had its equivalent in Gorizia near the western border of Carniola. The second China-based Jesuit from Austrian Province after Kirwitzer (1588/1590-1626) was Koffler (16121651), who resided in Ljubljana before he embarked for Far East. In 1636/37 in Ljubljana he taught rhetoric as the collaborator of the professors of the casuistic Ferdinand Montegnana (1599-1674) and the first distinguished historian of Slovenian origin Martin Bavčer (Bautscher, 1595-1668 Gorizia). Their prefect of students, Janez Muschan (1599 Kamnik-1640 Ljubljana), was professor of mathematics as a student of the second year of theology in Graz in 1625. Muschan was classmate of Bavčer and Montegnana, who taught syntax in Ljubljana in 1625. Koffler certainly learned some mathematics from Montegnana, who later published about the squaring of circle, magical squares, and other funny problems in four paragraphs. Before the publication Montegnana was a confessor of the first prince Johann Weikhard Auersperg (1615 at Žužemberk Castle-11 November 1677) from Carniola who helped Otto Guericke (1602-1686) in his pioneering vacuum experiments (Lukács 1982, 285; Valvasor 1689, 4/6: 353, 8: 742; Montegnana 1673; Južnič 2004, 25-27).

Diestel, Mesar (Messari), and Hallerstein were all born in Carniola, which made Ljubljana college very important for future Chinese missionaries. Diestel taught in the first elementary class in Ljubljana, but Mesar never formally worked at Ljubljana College which owned vineyards nearby their respective native places in karst region. Their other fellow China-based missionaries from the Austrian province were born in Vienna (2), Linz (2), Silesia (1), and north of Graz (1), which makes small Carniola proportionally very important for Chinese missions.

Diestel and Mesar studied in Graz and in Gorizia respectively. Higher education in philosophical studies of Ljubljana was eventually established a year after 
Hallerstein's birth. Nonetheless, a quick overview of Ljubljana Jesuit facilities as a base for the education of future Chinese Jesuits might be helpful.

Between the foundation of the philosophical faculty in Ljubljana in November 1704 and the suppression of Jesuits in 1773 Ljubljana hosted altogether 663 Jesuits, among whom 501 were Masters of Philosophy. The others were temporary helpers who did not finish their studies at Universities.

In the 1650 s at least 40 future Ljubljana Jesuits studied philosophy in Graz (53\%). At least 20 studied philosophy in Vienna (26\%), and another 3 in Trnava. Two of them began their studies of philosophy in Vienna and finished in Trnava. The Alma Mater of 4 of them is harder to determine because they became Jesuits after they finished their studies of philosophy. Their studies were therefore not noted in Jesuit encyclopedias. From 1704 to 1773 the percentage of Graz philosophical students among Ljubljana Jesuits was lower than its 1650s score. In the eighteenth century, besides Graz, Vienna, and Trnava there were also other colleges that educated future Jesuits for the Ljubljana College.

Five (7\%) of altogether 75 Jesuit Masters and Fathers were employed in Ljubljana in the 1650s taught mathematics in Košice (2), Klagenfurt (1), Graz and Vienna (1), or Graz (1). 16 (21\%) of them taught physics in the second year of the philosophical triennium. They were professors in Graz (3), Klagenfurt (4), Vienna (2), Graz and Vienna (1), Klagenfurt-Graz-Vienna (1), Vienna and Leoben (1), Graz (1), Trnava (1), Zagreb (1), and Gorizia (1). Two professors of mathematics also taught physics. Among those 21 professors of physics and/or mathematics just 12 (16\%) published their works. Just 4 of them picked for their dissertation topics physics and/or mathematics. The technical know-how of Ljubljana Jesuits rapidly advanced after 1704, when Ljubljana developed domestic university-level studies of mathematics and physics. From 1704 to 1773 Ljubljana in average hosted each year more than one technical expert who as a magister of philosophy repeated professor's lectures of mathematical sciences, while in the 1650s, just one Ljubljana Jesuit accomplished such specialization in Graz. After 1704, much more Ljubljana Jesuits taught philosophy in other colleges, but professors of more demanding mathematics still remained a rarity (Lukács 1982; Jesuits 1730-1773). The mathematics of those days included mathematical application of mechanics, optics, and astronomy (astrology).

\section{Chinese Scientific Network}

The Chinese-Manchu educational network based on the imperial examination system had a much older uninterrupted tradition compared to European universities. 
On the other hand, (scholastic) Natural Philosophy was developed exclusively in European medieval universities. Those studies were a necessary prerequisite for acquiring the degree of Masters of Arts at about 65 European Universities with thousands of students graduating yearly in the period from 1250 to 1550 . The graduates carried their know-how to their future destinations, where it became a part of the cultural circles of upper class. The European medieval universities were similar but different than the educational organization in ancient Rome, Byzantium, Islamic Countries, or China. The European universities developed and nursed the tradition of "probing and poking around" in the tradition of scholastic debates subordinated to the strict rules of Aristotelian logic. They studied in the spirit of early modern scientific inquiry, which endorsed some kind of systematic doubt later endorsed by Cartesians. Natural philosophy could flourish in spite of a low level of exact sciences, but exact sciences stagnated without the flourishing of natural philosophy and business-incorporated crafts. Therefore Babylonian, Indian, and probably also Chinese mathematicians did not prosper without the useful and state-supported natural philosophy applied to profitable crafts, although the calculus of Newton and Leibniz was a product of Jesuit missionaries' exports from Cochin (Kochi) in Indian Kerala and Goa, where Matteo Ricci taught from September 13 1578, to April 15 1582. The Indian mathematics network spread to the Jesuit Roman headquarters, as well as to Beijing, where Hallerstein's collaborator Ming'antu (Ming Antu, Myangat, 明安圖, about 1692 in Sharaid Clan based in Urt Tsagaan Khoshuu in Mongol-1764) published the power-series expansion for the trigonometric functions of the number $\pi$. European natural philosophy needed reason based on the economy of profit and not the ecclesiastical authority that made it suspicious in Islamic states (Grant 2007, 324-8; Raju 2007; Joseph 2011, 304-5, 434-5). In the Christian countries, universities and their natural philosophy at least got some sort of modus vivendi, a tolerant contract in spite of disagreement. European authorities, the churches included, learned to tolerate the critical spirit of universities because of the economic profits the students provided for their professors. That minor profit multiplied after the scientific revolution, when academic know-how became the motor of the extremely immoral profitable industrial revolution, which spread predominantly through Western Europe in the first place, and reached the other parts of the world after huge delays.

Chinese natural philosophy lacked the connection with mathematics necessary for the development of an accurate calendar. Chinese mathematical astronomy (astrology) very early needed Mongolian and later the Jesuits' help to prevent the grave errors in predictions of eclipses and other unusual events which might humiliate imperial reputations. The network of Chinese-Manchu education relied too much on Chinese classics to endorse the challenges of developing crafts. The 
Jesuits were helpful in teaching the Emperor and his courtiers, but their connections with the practical craftsmen were too sporadic to stimulate inventions comparable to European steam-engines.

\section{Mutual Interchange between Central European Scientific Network of Austrian Jesuits' Province and Chinese Scientists}

The problems with calendrical and astronomical instruments forced Beijing court officials to seek the help of foreigners. In the decades of sporadic encounters with Jesuits, the Beijing rulers recognized the superiority of Matteo Ricci and his Jesuit colleagues in several branches of mathematics and cartography. Applied mathematics, later also painting and several crafts including clock-making, proved to be the useful platform for mutual exchange between Chinese-Manchu and Jesuit knowledge networks. The European Jesuits' educational system of Ricci's Roman teacher Christopher Clavius' and its branches were quickly designed to meet Beijing's imperial demands. The modifications on the Chinese-Manchu side included mostly the European astronomical tables and applied geometry. Despite connections with Indian Kerala, infinitesimal calculus was not extensively used in 18th century China. It never replaced geometry in the Jesuits' framework like it did in the framework of Parisian Encyclopedists. In 1738, the mutual feedbacks between Beijing native scientific network and Jesuits' network stimulated Kögler, Pereyra, the Mongolian Ming'antu, and later also the young Hallerstein to produce the Lixiang kaocheng houbian (暦象考成後編, the new edition of the final laws for the calendar and astronomical instruments, published by order of the emperor). Ignaz Kögler edited it in 1742. Kögler's collaborators endorsed the theory of parallax, the refraction of light in atmosphere, and Kepler's first two laws with elliptic trajectories of the Sun and Moon. Kepler's improvements of Copernicus' system were used in Tycho Brahe's system but they were not applied to the orbits of the planets. Kögler, Hallerstein, and their collaborators at least partly fulfilled the job that Tycho had expected in vain from his assistant Kepler one and a half century earlier, in 1600. Kepler did not trust his master Tycho and used Copernicus' model instead. In Europe, the system of that Kepler-Tycho kind was rarely used, for example in the work of Richelieu's cosmographer Noël Duret (Natalis Durret, 1590-1650 Paris) soon after Kepler's death. In that extraordinary way, Tycho Brahe's system had to wait 150 years to flourish-in Beijing. Tycho would have certainly been pleased! (Shi 2000, 147; Yusheng 2000, 219, 221; Kobayashi 2002, 11; Zurndorfer 1988, 74-75; Ben-Zaken 2004, 1, 2, 71, 21; Martzloff 1993, 224; Sivin 1965, 201). 
Other lesser known examples of the feedback from the Beijing Jesuits' network back to Europe included their research on the electrophorus, which endorsed much less imperial attraction, but eventually influenced Alessandro Volta via the Beijing Jesuits' correspondents in St. Petersburg (Južnič 2009, 134-41). Both examples were the products of Jesuit scholarship in Beijing under hardly recognizable domestic Chinese-Manchu influences. While the history of Chinese-Manchu pure and applied mathematics proved to be especially interesting for European experts in Paris, it is hard to recognize the Chinese-Manchu influence on late 18th-or early 19th century European pure and applied mathematics of non-Euclidian geometry, Sadi Carnot's theory of the steam-engine, Galois' theory of groups, or Central European Ludwig Boltzmann's statistical mechanics. The European sciences related to statistics were probably influenced by the Chinese-Manchu bureaucratic know-how. For centuries the Chinese more or less successfully governed the mass of their subjects, who to unaccustomed European eyes were seemingly indistinguishable from one another, as were the Europeans for Chinese observers. Atoms and also rays of light of similar color were inseparable from one another in the last two centuries of European Sciences. They resembled in their own way the huge mass of seemingly identical Chinese humans.

\section{General Gabriel Gruber's Abortive Restoration of Chinese Jesuits}

Gabriel Gruber (May 6, 1740-April 7, 1805) was a relative of the Chinese missionary Johannes Grueber. Their families prospered in the broader areas of Linz and Amstetten in Upper Austria. Gabriel spent his formative decades in hydro-engineering in Ljubljana. His applications for the Chinese missions were never approved. As the Jesuits' general in St. Petersburg he reestablished the Jesuits' network worldwide including China. Gruber's main Beijing supporters were the physician Cipolla, the painter Poirot, and musician-mathematician Grammont (1736-1812?).

Hallerstein's Beijing assistant in astronomical observations Luigi Cipolla (Aloys Cibolla, Louis, 1736 Caltavuturo near Palermo in Sicily; SJ 1757 Sicily; - after 1805 (Pfister 1934, 964-5; Dehergne 1973, 56)) studied medicine because the Chinese needed physicians and painters at the time. On March 20 1770, Cipolla and Louis de Poirot (Ho Ts'ing-T'ai, 1735 Lorraine; SJ 1756 Florence in Roman province; -1813 Beijing (Pfister 1934, 965-6; Dehergne 1973, 207; Zalenski 1886,2:136)) departed from Europe, and they dropped their anchor in Canton on October 20,1770. Cipolla and Poirot arrived to Beijing on August 14 1771. After the suppression of the Jesuits Society Cipolla was the propagandist 
in Beijing in 1776. Although he was initially in the French mission, Cipolla asked to join the Portuguese mission. As a member of the Portuguese mission he became a member of the astronomy bureau under Hallerstein's supervision. In September 1802, Poirot joined the Russian Jesuits of the former Ljubljana professor G. Gruber. Cipolla put the similar demand in 1805. Gruber had a hard time to convince Cipolla. To his own letter of invitation Gruber added the note of Cipolla's friend from their youngsters' years spent in Sicily, Eduardo Desperamus (1737 Chios; SJ 1751 province of Sicily, 1803 Petersburg; -1812), the rector's assistant in Polotsk in (White) Russia (Inglot 2002, 358; Moroškin 1870, 2: 110, 333; Inglot 1997, 214).

Most of the Beijing Jesuits, including Jean-Denis Attiret (Dyonysis, 1702 Dole; SJ 1735 Avignon; -1768 Beijing), praised the path irregularly arranged in the Emperor's gardens but the painter Poirot criticized the garden in his letter signed on October 3 1772. Poirot translated the Bible into Manchu and Chinese and worked as a translator during the visit of the Lord James McCartney (4 May 1737-31 May 1806) in China in 1793. For those merits the Emperor Qianlong 乾隆 (1711-1799) appointed Poirot a mandarin (Koláček 1999, 27; Inglot 2002, 358; Rinaldi 2006, 263). The Catholics Gruber and Poirot might even dislike the intentions of the Protestant James McCartney in China.

Jean-Baptiste-Joseph de Grammont (1736; SJ 1750; -about 1812 Beijing) and artist Joseph Panzi (1734; SJ 1768;--before 1812 Beijing) renewed their vows to the Jesuit society in 1806. With all remaining five China-based Jesuits (Cipolla, Poirot, Panzi, Almeida, and Grammont) as his local supporters, Gruber was on his way to reestablishing the Jesuits' network in Beijing. The Jesuit general Gruber sent three Russian Jesuits to China in January 1805, but the Propaganda Fide stopped the process from Rome. The leading Beijing-based ex-Jesuit astronomer of G. Gruber's time was the director of the Beijing Astronomical Bureau and physician-pharmacist skilled in calendar calculations José Bernardo de Almeida (Suo Dezhao, Yué-Tch'ang, 1729 Portugal; SJ February 23 1746, Arrojas; -November 12 1805, Beijing (de Abreu 2004, 200, 232)). According to Pfister $(1934,886)$ Almeida was born earlier, on January 151728.

\section{(Jesuit) Western Learning versus the Chinese Learning}

The Jesuits' approach to foreign cultures based on Ricci's accommodation principle was ethically superior to the approaches of other Christian religious orders and of European rulers in general. The Jesuits did not wish to annihilate foreign frameworks or even humans behind them, but tried to endorse foreign similarities, 
even if that caused some minor changes in their own European framework. The Ricci's accommodation principle proved to be extremely helpful in Guaraní Paraguay, China, and G. Gruber's Orthodox Russia. In the latter two cases there was even some hope for Constantine's type of conversion of the whole Empire from the top to the bottom, but it failed after the Jesuits lost the Chinese Rites Controversy and the Emperor Paul I was murdered in Petersburg. In Guaranís case the conversions were much less imposing because there was no authoritative Guaraní leader to deal with.

Ricci's accommodation principle could mean some danger of foreign non-European influence on Catholic Headquarters in Rome, which we are probably still witnessing today after the election of the Argentinean Jesuit Pope Francis. The Chinese Rites Controversy over the religiosity of Confucianism and Chinese rituals brought a major defeat to Jesuits. It was also a major error of the leadership of the Roman Catholic Church, comparable to the earlier erroneous condemnation of Galileo and later suppression of the Jesuits. The policy of accommodation is the conditio sine qua non of modern globalization and Ricci's soft approach seems to be attractive. It is related to the modern trends to preserve non-European civilizations from annihilation, and even to learn some ecological issues from them.

Cortes' Mexico (1519-1521) or Pizzaro's Peru in 1532-1533 (Diamond 2008, $67,70,75)$ could have been less cruel with some Jesuits involved, but St. Ignatius founded the Jesuits just several years after the Aztecs and Incas were stripped of their power. Cortes, his relative Pizzaro, or modern European-American conquerors of Near East oil fields used the very opposite of Constantine's approach by killing the ruler and his courtiers to steal their supposed goods. Afterwards they tried to convert the rest of the conquered nation left without an official leader, which seems to be successful in Latin America but not in the Near East head-

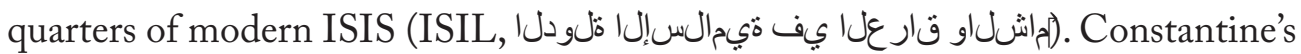
conversion from the top, enriched by Ricci's principle of accommodation, seems to be much more profitable in the long run. Accommodation seems to be the right approach if we compare the flourishing Jesuit Guaraní Paraguay Residences with the impoverished areas of the rest of Latin America. The striking difference between forced conversions and Ricci's principle of accommodation is also in their timing: should the aggressor grab all the resources of the defeated instantly, or should the aggressor allow the defeated to develop and adapt their own native economy for the aggressors' future profits? The English cruel transfer of 3.5 million enslaved West Africans to America was far enough from Ricci's principle of accommodation. The English profits probably never really outweighed the humiliation of all human principles involved. In many cases of European aggression, it was far too late to repair anything because almost nothing was left after the 
seemingly inferior groups of people were "civilized". But after humanity endorses the obvious truth that imperialism was a crime, the descendant of enriched imperialists should repay in ready money the damage their ancestors have committed. That would be the only way to prevent the future repeating of damaging racist aggressions and to reintegrate the soft Ricci's principle of accommodation for the benefit of future mankind.

\section{Projection: What Kind of Science Will Western Civilization Import from the Future Chinese?}

The sciences that the Chinese and Manchu learned from the Jesuits of the Old Society during both centuries of the Jesuits' Chinese network operation profoundly influenced Chinese-Manchu knowledge. The Western-Eastern global conglomerate endorsed some valuable and even unique results produced in both centuries of the intensive mixing of the Jesuits' imported scientific network and the Chinese domestic network. Among them was the use of Kepler's laws in Tycho's system, the early electrophorus, and valuable astronomic observations published in Europe. The Jesuits' transfer of sciences to China also endorsed some dynamical changes visible in French Michel Benoist's (Benoît, Tsiang Yeou-Jen Tö-Yi, 1715 Dijon; SJ 1737 Nancy;-1774 Beijing) presentation of Copernicus' heliocentrism, with a map for the Emperor's birthday in 1760. Copernicus finally replaced Tycho Brahe's system in China only at the end of the eighteenth century (Wong 1963, 46; Sivin 1973, 95; Zurndorfer 1988, 75, 88; Yusheng 2000, 225; Needham and Ling 1959, 3: 443-4), which was one of Copernicus' last victories worldwide.

After two and a half centuries those failures and successes of China-based Jesuit scientists still affect the Chinese approach to modern sciences. Niels Bohr's (7 October 1885-18 November 1962) lectures in China in 1937 developed the deep link between Bohr's concept of complementarity and the Chinese notion of the polar opposites yin and yang. Bohr admired Jesuit Rudjer Bošković's (1711-1787) theories on force in Zagreb on October 29 1958. In 1969, Bohr's former collaborator Heisenberg (1901-1976) did the same together with Heisenberg's former Ph.D. student Ivan Supek (8 April 1915-5 March 2007). Bošković's science was widely accepted in the Habsburg monarchy after Bošković published his masterpiece in Vienna in 1758 and accepted the university chair of mathematics in Habsburg Pavia in 1764. Hallerstein used Bošković's theory of comets (1746) for his observations of comet C/1748 H1 between April 27 1748, and June 181748 (Južnič 2015, 5). Therefore it is hard to expect from modern Chinese to lead the frontlines against Bohr's Copenhagen interpretation of quantum mechanics. 
Einstein's brilliant lecture in Shanghai on New Year's Day of 1923 helped the Chinese to become one of the rare parts of the world that accepted Einstein's relativity without criticism. Later, Einstein's relativity theories suffered hard blows from Lenin-Marxist headquarters of "Cultural Revolution" up to 1979 (Hu 2005, 165-6). The Chinese already witnessed their huge ups and downs with Einstein's theories. If some guessing is permitted, we could expect the fundamental future Chinese achievements in cosmology, especially in Einstein's general theory of relativity.

\section{Transfer of Science at the Periphery and the Reverse Impact from Less Developed Centers of Far East}

Already in M. Ricci's time, reports about the Chinese crystalline spheres were denied by Giordano Bruno (1548-1600) in Europe in 1595. The Frenchman Jean Bodin (1530-1596) openly mocked Copernicus' followers in 1628. The idol of the London Royal Society, Francis Bacon (22 January 1561-9 April 1626), had no real understanding of the importance of mathematics when he opposed Copernicans and William Gilbert (1544-1603) as alleged alchemists. Bacon refused Kepler's theory of perspective, but Bacon described well fluorescence in combination with electricity, Fludd's thermometer, designed in 1605 and primarily called by the name of J. Leurechon in 1624, Drebbel's microscope, Galileo's telescope, distilling of spirits of wine, the differences in compressibility of different physical states, and scholastic opposition to the vacuum. Francis Bacon mocked the magic of the universal logic machine of Raymond Lull. Did their opinions influence contemporary European admiration for the Chinese people? To be sure, the knowledge and even technology was also transferred from China to Europe even if there were no direct contacts. Only Jesuits acted as intermediaries, and to some extent also Russian Orthodox Beijing missionaries and merchants. In 1980 Needham and Wang indicated the potential Chinese impact on their European admirers, including Leibniz. Some Korean and most Japanese scholars believed that Western scientific techniques cannot be taken outside of the cosmological and religious environment in which they evolved, which was also Toynbee's opinion. On the other hand, Toynbee believed that there was never any mutual interaction between the advances of techniques and civilizations. If the technique is one of the universal methods of modern scientific paradigms, then it is possible to attribute to the English empiricist Toynbee (and to the ecologist Diamond) even the doubts in any effective influences of the development of science on the developments of civilization. The impossibility or at least the troublesome mutual borrowing between the Chinese and Europeans in those decades was the result 
of their incommensurate paradigms, between which effective exchange and dialogue was not possible, although Thomas Kuhn (1962) was not thinking in such an international context because he was not sufficiently aware of the importance of Chinese sciences. The Chinese have borrowed from the Europeans mostly astronomy and mathematics with a few branches of mechanical engineering and arts. The Chinese borrowed almost nothing from European medicine, anatomy, physiology, mechanics, botany, agriculture, or even architecture, because these subjects did not interest them much. The European electrical engineering and vacuum techniques were also not widely endorsed in China after the Jesuits presented them to the Beijing court. Chinese medicine has worked well, despite the false anatomical notions that were soon unmasked by Japanese readers of Dutch books. Nathan Sivin (born 11 May 1931) counted nine self-sufficient sciences in China: mathematics, mathematical harmony, astronomy, astrology, medicine, materia medica or pharmacy, alchemy, geomantics, and physical studies. The cornerstone of Chinese science was not the mathematics of the modern European educational system, but history as the foundations of Confucian social harmony, perhaps similar to the social harmony that Toynbee attributed to the European Middle Ages. Precisely because of those foundations, the Chinese studied ancient writers because they believed that the old literati were already familiar with all the knowledge that was later lost in the centuries. The European Renaissance admirers of antiquity probably shared similar feelings, but the enlightenment critics of the European Middle Ages rejected them later. Chinese historical thought welcomed the corresponding idea that modern European know-how originated from inventions already endorsed in ancient China. Needham said that over the centuries Arab traders passed on to Europe the Chinese invention of the compass: unfortunately, there is no evidence that the Arabs knew of the compass so early. The Chinese used a wind turbine for pumping water for thousands of years before the Europeans. However, similar wind turbines occurred in Europe in 1716, twenty-three years before the first known drawing came from China to Europe, and the Swedes started to explore the Chinese models only in the 1760s. The former printer Balzac in his story about the printer Séchard described Séchard's search for the better paper on Chinese patterns, which in Paris certainly happened, although the Chinese methods of paper production were based on bamboo. The paper became particularly interesting for the Europeans early in the 19th century with the boom of newspaper production, but already in Rheticus' times paper was the main wealth of writers. However, neither ancient Greece, Islamic peoples, nor the Chinese staged a scientific revolution comparable to that of the west in the 17th century, which remains the big question in the history of science. The multitude of independent Renaissance manors and courts of Europe probably offered the scientists better and more options in poor scientists' search 
for the wealthy patrons compared to the monolithic Chinese court, which was not able to provide for the efficient mixing of scientists and craftsmen comparable to the London Royal Society. On the other hand, the ecological problem of the modern world could be seen primarily as an attempt of the Chinese (or Africans, Indians, Native Americans, or Indonesians) to copy Western development under the influence of television and western consumerist propaganda (Gilbert 1991, xii, xvi; Bacon 1968, 27, 43, 124, 196, 207-9, 216, 230, 242, 244; Grant 2007, 280; Ule, 2006, 102; Bray, 1991, 205-8, 212, 215, 216; Toynbee, 2002, 497; Sivin 1985, 39; David 2008, 12-13, 66, 86; Diamond 2007, 392-3, 395). Westerners do not want them to compete with Western industries therefore they also support strict ecology to stop non-European economic development and to keep others poor. On the other hand even the question of the non-western non-existence of earlier industrial and scientific revolutions should be reversed in changing the economical patterns of success of Far-Eastern economies, which challenge the previously victorious Westerners' right to write history as an apology of their own success in the old-fashioned truth that the winners always dictate historical truths to hide their own sins. The modern Far-Eastern question, written on behalf of their worldwide winning economies, should be: did the Far-Easterners manage to overrun the Westerner economy precisely because they were able to avoid the earlier industrial-scientific revolutions that somewhat dogged the Westerners' developments in the modern Anthropocene? The era of Eurocentrism is certainly over for good; therefore we need a new paradigm, but we should not endorse a similar kind of Far-Easterner-centrism, but some more balanced approach in between.

\section{Conclusion}

The future certainly is as uncertain as it always has been. But one thing could be stated for sure: the (European-American produced) history of science treated the achievements of non-whites of past centuries extremely unfairly. Females and socially-unprivileged groups suffered similar neglect regarding their past intellectual abilities. As always in history the pendulum will for a while stay in the opposite extreme. Some humiliations of white European males' achievements will take place. Later, a kind of agreements about the mutual merits will be endorsed in the globalized world of modern times called Anthropocene.

The most important challenges in the history of science followed after the introduction of new previously neglected groups of researchers. In that context the huge changes happened when the urban and rural capitalists' sons in the times of Galileo and Newton earned the opportunity to became the full-time scientists. 
The third estate in French Revolutionary times followed by the Napoleonic universal state brought the educated sons of previously unimagined socially low pedigrees to European full-time research positions. The peasants and other previously unprivileged groups joined the educational-scientific networks after the Spring of Nations of 1848 in the Central European cities, in post-tsarist Russia, and after the communist revolution in China. The new paradigms of sciences are expected in modern times with the full time scientific research of emancipated females and non-whites' based on equal opportunities. The long-neglected and unpublished inherited worldviews of previously uneducated Chinese peasants will bring their share. That is where the Chinese feedback on European sciences is expected to flourish.

Many notions of Chinese feedback are already visible. The globalized chaotic rebellious youth provided the new challenges in 1968. Globalization promoted the theories on quasi-crystals of the Chinese-educated Harvard mathematician Hao Wang (王浩; Wang Hao; 1921-1995) in 1961. Hao Wang's Chinese-American novelties were upgraded with chaos theory and the fractals of Polish Jewish IBM computer expert Benoit B. Mandelbrot (1924-2010) in 1975. The network theories provided examples of sociological feedback on mathematical sciences after the Bucharest born Jewish psychiatrist Jacob Levy Moreno (May 18, 1889-May 14, 1974) constructed his sociogram as a rival to Freud's psychoanalysis at Columbia University in New York City. The sociologist and psychologist Dorwin Cartwright (1915-2008) and the mathematician, Syrian-Morocco Jew Frank Harary (March 11, 1921-January 4, 2005) from the University of Michigan in Ann Arbor, included Moreno's sociograms in mathematical graph theory based on Leonhard Euler's network theory developed in St. Petersburg in the 1780s. At the University of Michigan one of Harary's collaborators was Dutch physicists George Uhlenbeck (1900-1988), a student of Boltzmann's Viennese Jewish student Paul Ehrenfest (January 18, 1880-September 25, 1933). New York Jewish social psychologist Stanley Milgram's (1933-1984) small world experiment, the sociologist Mark Granovetterov (1943-), the Jews from Budapest Pál Erdös (1912-1996), and Alfréd Rénuyi (1921-1970) soon proved the similarities of economic, sociologic, physics, and mathematical schemes. The widespread popularity of network theories developed through the research of mathematicians and physicists who grew up after the youth revolts of 1968. The mathematicians from Columbia University and Cornell University in New York City Duncan J. Watts (born 1971) and Steven H. Strogatz (born August 13, 1959) published their Collective dynamics in 1998. Strogatz stayed in Cornell while Watts moved to Yahoo! Research and in 2012 to Mircrosoft Research in New York City. His move echoed new trends of business-oriented research, which became distinguished from 
traditional academic careers. The non-western physicists, like Romanian-born Hungarian Albert-László Barabási (born March 30,1967) and Slovenian Matjaž Perc (born in 1979), entered the network's theories through the research on chaos in the 21st century. In his examples of network spread, Barabási included even the spread of early St. Paul's Christianity. The network's ideas certainly spread worldwide as a kind of network itself supported by literature like the modern crime novels of John Grisham (born 1955) starting with The Firm released by Random House in 1991, and inspired by Chicago Al Capone's mafia background. Their mathematical treatments of modern networks fits especially well the Old Society of Jesus' successful network of scholars within the Jesuits' monopoly on Catholic continuing education and the initial success of their Chinese mission. The operations of the Jesuits in China and elsewhere could be treated with modern statistical approaches to the theory of networks with one important difference: the theory of networks largely considered a decentralized organization, those networks without spiders in the hubs. The Jesuit network was strictly militarily centralized through the local rectors, their provincials, and all the way to the Jesuit general. In the case of the China-based Jesuits there was actually more than one spider in the hub in the Jesuits' network. Besides the Roman Papal and Jesuit General's headquarters, the Imperial court in Beijing also had to be considered as another center of decision-making and information-gathering. The same was also true for the Jesuits' collection and processing of scientific data. For example, most of the Jesuits' missionary and other reports were collected in Rome, where Athanasius Kircher acted as a unique mailbox, qualified for the processing of data and their publication in heavy tomes in the 17 th century. His role was similar to Marin Mersenne's (8 September 1588-1 September 1648), who was Kircher's decadeand-a-half-older French contemporary. The Jesuits of the Old Society had great advantages from their missionary work, especially in China and Paraguay. A large share of confessors in important Catholic royal courts also belonged to the Jesuits, especially in the Habsburg Monarchy. For example, the younger brother of A. Hallerstein was a confessor of the brother-in-law of the Empress Maria Therese in Brussels. The monopoly in Carniola and other Habsburg schools, with the exception of basic primary schooling, belonged to the Jesuits, and that fact enabled Jesuit teachers to recruit the most promising students to their Jesuit Order.

Arnold Toynbee's five-stage model of the development of civilizations and their universal churches proved to be useful tool for a description of development of scientific paradigms (Južnič 2012, 34-9). It endorses somewhat more than just an analogy because medieval Völkerwanderung seems to have unavoidable similarities with the modern brain drain of mostly colored populations to white Western academic institutions. It is therefore fair to suppose that the consequences might also 
prove their similarity with the previously outwardly barbarous proletariat successfully struggling for new scientific paradigms in the global modern word. The bourgeoisie changed scholastic science with the intervention of Galileo and Newton in the times when scientific education became available to a greater number of the citizen-class's sons compared to previous feudal times. In the French context, the next group of previously scientifically disregarded people got the chance for education after the French Revolution of 1789. The new wave of top Parisian scientists included the mechanics of a farmer's son, Laplace, or the descriptive geometry of a provincial merchant's son, Gaspard Monge (9 May 1746-28 July 1818). In the (Central) European context, the next group of previously scientifically disregarded people, namely peasants, got the chance for education on (nearly) equal opportunities after the Spring of Nations in 1848. The came happened in China after the Communist Revolution in 1949. That new large group of people mirrored their domestic environment with the reform of ancient atomistic views based on modern statistics of undistinguishable particles similar to undistinguishable hordes of unnamed inhabitants of growing world metropolises. That statistical novelty in sciences was also influenced by European awareness of the numerous inhabitants in China.

Other great Volkerwanderung in the scientific field involved women, after their higher education was allowed almost worldwide in the late 19th century. The feministic revolution could eventually follow Thomas Kuhn's (July 18, 1922June 17,1996) model in spite of the fact that Kuhn himself was not aware of it (Longino 2003, 281). Marie Curie (7 November 1867-4 July 1934) and Lise Meitner (7 November 1878-27 October 1968) were the first female chemists in the male world of physics with their main contributions related to the research of radioactivity decay. The Gottingen student of Max Born (11 December 1882-5 January 1970) and James Franck (26 August 1882-21 May 1964), the German Maria Mayer née Goeppert (1906-) from now Polish Katowice, followed Marie Curie, with her 4-way tie for the Nobel Prize in physics in 1963. Her topics endorsed the research of nuclear shells after her work on the Manhattan project with Hungarian-born Edward Teller (January 15, 1908-September 9,2003). It is not easy to distinguish which aspects of those nuclear physics branches of sciences were influenced by the female nature of the researchers, but boring tiresome experimental work of that kind could just a passionate woman could do. The feminization of physics is in progress but the feminization of new paradigms in physic is yet to be seen.

With females entering scientific research the potential number of would-be literati was doubled. At approximately the same time as females, also natives of colored ancestry of Africa, Asia, Latin America, and the Pacific islands entered the world 
of professional scientific research. Previously uneducated Chinese peasants rushed to towns and brought their traditional worldviews with them. They multiplied the number of possible researchers of new paradigms. It is true that two Nobel Prize in physics delivered to females born in now Polish land and four female Nobel laureates in chemistry with two Curies included does not provide enough space for top female scientists, not to mention the female researchers from the third (colored) word. But the times they are a-changin' in Bob Dylan's song, and the times are also changing in the contemporary scientific research. The entrance of Italian cities' literati after the Reformation (1517) and the early years of the Thirty Years War (1618), the promotion of the English and Dutch bourgeoisie after the Glorious Revolution (1688), the French Revolution's Third Estate, the Central European middle class or peasant-born literati after the Spring of Nations, and the Chinese peasants in the second half of 20th century provided respectively very soon the new paradigms of Galileo, Newton, Lavoisier-Laplace-Volta, Stefan-Boltzmann, and modern networks. It seems that feminization and the coloring of the top researchers of modern science is not at all that quick, but sooner or later the quantity of newcomers must bring some new qualities in the output of their mutual research. It is true that 2 researchers from India (C.V. Raman 1930; Subrahmanyan Chandrasekhar 1983), 1 from Pakistan (Abdus Salam 1979), 6 from China with Hong Kong (Tsung-Dao Lee and Chen Ning Yang 1957; Samuel C. C. Ting 1976; Steven Chu 1997; Daniel C. Tsui 1998; Charles K. Kao 2009), and 10 Japanese (Hideki Yukawa 1949; Sin-Itiro Tomonaga 1965; Leo Esaki 1973; Masatoshi Koshiba 2002; Makoto Kobayashi, Toshihide Maskawa, Yoichiro Nambu 2008; Hiroshi Amano, Isamu Akasaki, Shuji Nakamura 2014) were Nobel laureates in physics, but most of them worked in the United States or were even born there. The colored and female breakpoints in physics are yet to be seen in the 21st century. The deep question is, what did the Third Estate, females, or non-whites think about the scientific questions before they were allowed to take the educational and research advantages in mainstream European Christian Sciences and their trans-Atlantic siblings. Did they live the centuries of their lives without any recordable scientific developments, or their achievements were and still are just hidden from the modern historian of science under the heavy burden of different frames, languages, observational practices, and ways of thinking? What was the "scientific" opinion of Chinese peasants before they were able to educate their children in late twentieth century? During all those centuries of suppression, were the socially de-privileged, females, and colored parts of the population really stupid enough not to think about the world around them, or we just do not understand their messages because not enough money was invested to research their achievements? The answer must be much nearer to the later supposition, but only the Chinese case provides 
some insight in Chinese achievements before the Jesuits "discovered" Chinese for the Westerners. Joseph Needham (1900-1995) and his Chinese collaborators were certainly the ones who uncovered Chinese achievements to Europeans, but African, Aborigine, Native American, or Pacific island Needhams are still waiting for their turn (Norris and Hamacher 2009, 10-17; Norris 2014).

The discussion proved the importance of central European China-based Jesuits in the global Jesuit network, designed to provide for the mutual cultural, scientific, and technological interchange between the Chinese and European literati's networks. The immediate effect of the interchanges, or rather of their abrupt end after the suppression of the Jesuits, was the humiliating Chinese military defeat in the Opium Wars before and after European Spring of Nations. After a century of humiliations and neglect the Chinese networks' challenges are relevant again and the history of China-based Jesuits of the old society needs to be rewritten from the Chinese standpoint. The present study is a small step of American-born European historians and physicists towards that goal.

\section{References}

de Abreu, Antonio Graca. 2004. D. Frei Alexandre de Gouveia, Bispo de Pequim (1751-1808): contribuição para o estudo das relaçôes entre Portugal e a China. Lisboa: Centro de Estudos dos Povos e Culturas de Expressão Portuguesa da Universidade Católica Portuguesa.

Amiot, Jean-Joseph Maria. 1774. "Observations météorologiques faites à Pékin, par le P. Amiot, Décembre 1762. Mis en ordre par M. (Charles) Messier.” Mémoires de mathématiques et de physique, présentés à l'Académie Royale des Sciences. 6: 519-601.

Bacon, Francis. 1968. Novum organum. Bari: Laterza.

Ben-Zaken, Auner. 2004. "The Heavens of the Sky and the Heavens of the Heart: the Ottoman Cultural Context for the Introduction of PostCopernican Astronomy." British Journal for the History of Science 132 (March) 37 (1): 1-28.

Bray, Francesca. 1991. "Some Problems Concerning the Transfer of Scientific and Technical Knowledge." In China and Europe, Images and Influences in Sixteenth to Eighteenth Centuries, edited by Thomas H.C. Lee, 203-19. Hong Kong: Chinese University Press.

David, Paul A. 2008. “The Historical Origins of 'Open Science': An Essay on Patronage, Reputation and Common Agency Contracting in the Scientific Revolution." Capitalism and Society 3 (2/5): 1-103. 
Diamond, Jared. 2007. Propad civilizacij. Tržič: Učila International.

- 2008. Puške, bacili in jeklo. Tržič: Učila International.

Dehergne, Joseph. 1973. Répertoire des Jésuites de Chine de 1552 à 1800. Rome: Institutum Historicum S.I.

Dežman, Karel. 1881. "Ein Krainer als Hoffastronom in Peking 1739-1774." Laibacher Wöchenblatt. Organ der Verfassungs - Partei in Krain. Gedr. bei Leykam in Graz 50-55: 1-20. Laibach: Kleinmayr \& Bamber.

Gilbert, William. 1600. De Magnete. Londini: Petrus Short. (Reprint: 1991. New York: Dover)

Grant, Edward. 2007. A History of Natural Philosophy from the Ancient World to the Nineteenth Century. Cambridge: University Press.

Hu, Danian. 2004. China and Albert Einstein: The Reception of the Physicist and His Theory in China. Harvard: University Press.

Inglot, Marek. 1997. La Compagnia di Gesù nell'impero Russo (1772-1820) e la sua parte nella restaurazione generale della Compagnia. Roma: Editrice Pontificia Università Gregoriana.

Inglot, Marek. 2002. "Gabriel Gruber, S. J. (1740-1805): nel bicentenario della sua elezione a generale della Compagnia di Gesù." Archivum historicum Societatis Iesu 71 (142): 353-68.

Jesuits. 1730-1773. Catalogus personarum E' officiorum Provinciae Austriae Societatis Jesu. Wien.

Joseph, George Gheverghese. 2011. The Crest of the Peacock: Non-European Roots of Mathematics (Third Edition). Princeton: University Press.

Južnič, Stanislav. 2004. Zgodovina raziskovanja vakuuma in vakuumskib tehnik. 1. del. Ljubljana: Društvo za vakuumsko tehniko Slovenije.

—. 2009. "Vacuum and Eletricity for Chinese Emperor." In A Hallerstein - Liu Songling - A Multicultural Legacy of Jesuit Wisdom and Piety at the Quing Dinasty Court, edited by Mitja Saje, 119-57. Maribor: Association for Culture and Education Kibla.

—. 2012. “Toynbee Nonsense Book for Slovenians." Studia Historica Slovenica 12 (1): 21-54.

—. 2015. "Bibliometrics of Jesuit Mathematicians in China." Historia Scientiarum 24 (3): 1-26.

Kaminski, Gerd, and Else Unterreider. 1980. Von Österreichern und Chinesen. Wien: Europaverlag.

Kaminski, Gerd. 1996. “Das Chinabild der Österreicher.” In Aodili. ÖsterreichChina. Geschichte einer 300jährigen Beziehung, edited by Gerd Kaminski and Kreissl, Barbara, 32-49. Vienna: ÖCGF.

Koláček, Josef. 1999. Č́nské epištoly. Velehrad: Refugium Velehrad-Roma. 
Kuhn, Thomas S. 1962. The Structure of Scientific Revolution. Chicago: University of Chicago.

Laimbeckhoven, Godefridus. 2000. Der Bishof von Nanking und seine Briefe aus China mit Faximile seinem Reisenbeschreibung. Sankt Augustin: Institut Monumenta Serica.

Longino, Helene. 2003. "Does the Structure of Scientific Revolution Permit a Feminist Revolution in Science." In Thomas Kubn, edited by Thomas Nickles, 261-81. Cambridge: University Press.

Lukács, Ladislaus. 1982. Catalogi presonarum et officiorum Provinciae Austriae S.I. II (1601-1640), Roma: Institutum Historicum S.I.

Martzloff, Jean-Claude. 1993. "Espace et temps dans les textes Chinois d'astronomie et de technique mathématique astronomique aux $\mathrm{XVII}{ }^{\mathrm{e}}$ et XVIII' siècles." L'Europe en Chine 217-30.

Montegnana, Ferdinand de (anonimous). 1673. Tractatus de Quadratura circuli. Viennae.

Moroškin, Mihail Jakovlevič. 1870. Iezuiti v Rosii: s carstvovanija Ekaterini II-i i do našego vremeni. Čast vtoraja, obnimajuščja istoriju iezuitov v carstvovanije Aleksandra I-go. Sankt Peterburg: Vtoro Otdelenije Sobstvenoi Ego Imperatorskog Veličanstva Kancelarii.

Mungello, David E. 2009. The Great Encounter of China and the West, 1500-1800. Lanham: Rowman \& Littlefield.

Needham, Joseph, and Wang Ling. 1959. Science and Civilization in China. Vol. 3. Mathematics, Astronomy, Geography, Cartography, Geology, Seismology and Mineralogy. Cambridge: Cambridge University Press.

Norris, Ray P., and Duane W. Hamacher. 2009. "The Astronomy of Aboriginal Australia." In The Role of Astronomy in Society and Culture Proceedings IAU Symposium No. 260, 2009 D, edited by David Valls-Gabaud and Alexander Boksenberg, 10-17. Cambridge: Cambridge University Press.

Norris, Ray P. 2014. "Aboriginal People - How to Misunderstand their Science." The Conversation April 20.

Pfister, Louis. 1934. Notices biographiques et bibliographiques sur les Jésuites de l'ancienne mission de Chine 1552-1773. II. Chang-hai: Imprimerie de la Mission Catholique.

Raju, Chandra Kant. 2007. Cultural Foundations of Mathematics: The Nature of Mathematical Proof and the Transmission of the Calculus from India to Europe in the 16th c. AD. Delhi: Pearson Longman.

Rinaldi, Bianca Maria. 2006. The Chinese Garden in Good Taste: Jesuits and Europes Knowledge of Chinese Flora and Art of the Garden in the 17th and 18th Centuries. München: Meidenbauer. 
Shi, Yunli. 2000. "Eclipse Observations Made by Jesuit Astronomers in China: a Reconsideration." JHA 31: 135-47.

Sivin, Nathan. 1965. "On 'China's opposition to Western Science during Late Ming and Early Ch'ing'.” ISIS 56: 201-5.

—. 1973. "Copernicus in China." Studia Copernicana 6: 63-122.

—. 1985. "Why the Scientific Revolution Did Not Take Place in China - or Did it?" The Environmentalist 5 (1): 39-50.

Stoeger, Joannes Nepomuk. 1855. Scriptores Provinciae Austriacae Societatis Jesu ab ejus origine ad nostra usque tempora. Viennae: Typis congregationis mechitharisticae.

Tatsuhiko, Kobayashi. 2002. "What Kind of Mathematics and Terminology Was Transmitted into 18th Century Japan From China." Historia Scientiarum 12 (1): $1-17$.

Toynbee, Arnold. 2002. Proučavanje Historije. Beograd: JP službeni list SRJ. Ule, Andrej. 2006. Znanost, Družba, Vrednote. Maribor: Aristej.

Valvasor, Janez Vajkard. 1689. Die Ehre deß Hertzogthums Crain. LaybachNürnberg: Wolfgang Moritz Endter.

Wong, George H. C. 1963. “China's opposition to Western Science During Late Ming and Early Ch'ing." ISIS 54: 29-49.

Yusheng, Wang. 2000. "P. Andreas Pereira and His Contribution to Mathematics and Astronomy in China." History of Mathematical Sciences 219-6.

Zalenski, Stanislaw. 1886. Les Jésuites de la Russie-Blanche. Paris: Letouzeu et Ané. I-II.

Zurndorfer, Harriet T. 1988. "Vendre la science a la Chine au XVIII ${ }^{\mathrm{e}}$ siècle." Etudes Chinoises 7: 59-90. 